\title{
San Fernando Batteries in Portobelo - Panama: building materials characterization and the environmental impact evaluation
}

\author{
Chiara Ciantelli ${ }^{\text {a,c }}$, Alessandra Bonazza ${ }^{a}$, Cristina Sabbionia ${ }^{a}$, Rodolfo A. Suñé \\ Martínez $^{\mathbf{b}}$, Carmela Vaccaro ${ }^{\mathrm{c}}$ \\ a Institute of Atmospheric Sciences and Climate, ISAC-CNR, Bologna, Italy, c.ciantelli@isac.cnr.it, \\ a.bonazza@isac.cnr.it, ${ }^{b}$ Patronato de Portobelo y San Lorenzo, República de Panamá, rsunepps1@ gmail.com, \\ ${ }^{\mathrm{c}}$ Dipartimento di Fisica e Scienze della Terra, Università degli studi di Ferrara, Ferrara, Italy, vcr@unife.it
}

\begin{abstract}
The UNESCO site of San Fernando arises in the northern part of the Bay of Portobelo, on the Panamanian Caribbean coast, and belongs to a group of military fortifications erected during the XVIIXVIII centuries by the Spanish Empire. These defence structures were aimed at protecting the strategic outpost for the transoceanic trade, between the "New" and the "Old World", from the pirate attacks.

In order to safeguard this impressive site, the Institute of Atmospheric Sciences and Climate, ISACCNR (Bologna), the "Patronato de Portobelo y San Lorenzo" and the Department of Physics and Earth Sciences of the University of Ferrara have started a collaboration for characterizing and evaluating the state of conservation of the construction materials, considering the environmental impact on them.

Specifically this paper shows preliminary results obtained by mineralogical and petrographic characterization carried out by Polarized Light Microscopy (PLM), Environmental Scanning Electron Microscopy (ESEM-EDX) and X-Ray Diffraction (XRD) investigations.
\end{abstract}

Keywords: construction materials, environmental impact, Panamanian fortifications.

\section{Historical background}

\subsection{San Fernando construction}

Designed by the military engineer Ignacio Sala in 1753 and erected by Manuel Hernández in the period from 1753 to 1760 , the current San Fernando batteries are part of the third stage of Portobelo's Military Architecture, named after King Ferdinand VI of Spain.

The constructions arise on the northern side of the bay of Portobelo and they are formed by a Fort and a Hilltop Stronghold. Specifically, the first one is made up of a Lower and an Upper Battery, connected by a covered way, which nowadays is shown by its remains; while the second one is located above the Upper Battery, about 100 meters height above sea level. Together with the Santiago de la Gloria and San
Jerónimo ramparts, placed on the opposite coast, they represent the most strategic defence structures of the cove, allowing an attack from two frontlines of the enemy vessels which tried to penetrate the bay (World Monuments Fund, 2003; Tejera Davis, 2007; Gobierno Nacional República de Panamá et al., 2014).

\subsection{0th century and current situation}

From the beginning of the XX century until the 70 's the San Fernando Fortifications were described, by historical evidences, as mainly covered by vegetation, in particular the Lower Battery and the Stronghold, which were hidden by the forest. During 1970-71 the Instituto Panameño De Turismo (IPAT) performed the 
"Portobelo Pilot Plan" in order to develop a documentation and a conservation campaign, carrying out deforestation and consolidation works at the site (World Monuments Fund, 2003).

In 1980 all the Caribbean Fortifications of Panama were included in the World Heritage List of UNESCO (http://whc.unesco.org/en/list/135); evertheless, in 2002, an inspection of the World Monuments Fund described the Fort of San Fernando in a poor state of conservation (World Monuments Fund, 2003). Later, they have belonged to the List of World Heritage in Danger since 2012. One year later the Instituto Nacional de Cultura of the Panamanian Government developed a Risk Assessment Study and published an Emergency Plan in order to safeguard the sites. Unfortunately this plan has not been executed yet, but thanks to the Patronato of Portobelo and San Lorenzo on site staff, cleaning, maintenance and some consolidation works have been performed (Osorio Ugarte, 2015).

With the aim of enhancing the knowledge of these structures and allowing a better preservation of the site, the following preliminary analysis define a characterization of the raw materials utilized and an investigation of the environmental impact on the buildings.

\section{Environmental context}

Situated on the Atlantic side of the isthmus, the Portobelo defence complex arises in a inlet of the Caribbean Sea.

According to the Panamanian geographer and historian, Dr. Alberto McKay, Portobelo climate is classified as "Tropical Oceanic Climate with short dry season", characterized by temperature mean values around $25.5^{\circ} \mathrm{C}$ on the coastal area and $26.5^{\circ} \mathrm{C}$ in the continental part. Abundant precipitations may reach annual amounts of $4760 \mathrm{~mm}$, indeed the dry season has a brief duration of 4-10 weeks, with 40-90 mm of rain between February and March (Gobierno Nacional República de Panamá and Autoridad Nacional del Ambiente, 2010). These conditions allow high growth of vegetation, with high forest coverage, as aforementioned, also supported by the low urbanization of the bay, which can be considered a rural area especially on the side of San Fernando.

It has to be taken into account also the tidal variations, which affect the Lower Battery, being in proximity of the sea (Fig.1); indeed, even the inner part of the Fort is subjected to the water permeation.

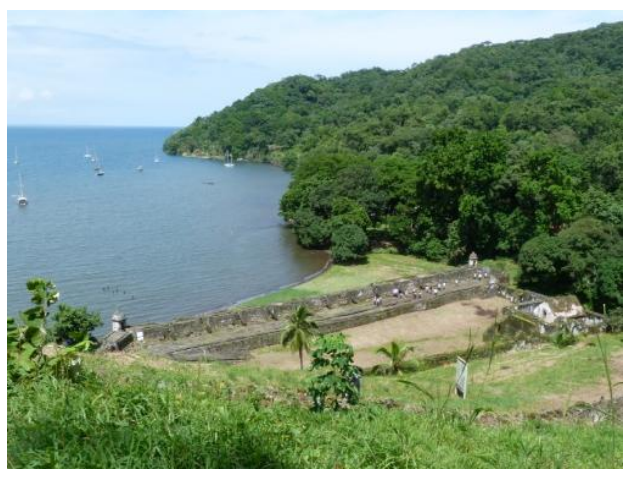

Fig. 1- Overview of the Lower Battery. The proximity of the sea is clearly visible.

\section{Materials and Methods}

Sampling was performed in each of the three components of the defence group, specifically collecting 11 samples of construction materials (stone, mortar and plaster); in addition salt efflorescences were sampled from the inner part of the moat.

In this paper, they will be shown only the results related to the stone materials, collected from the two Batteries (Table 1).

In order to carry out mineralogical petrographic characterization, polarized light microscopy (PLM) observations were performed on thin sections using an Olympus BX 51 microscope, equipped with scanner and the MICROMAX software "Primoplus_32" vers. 8.11.02.. In conjunction, both on thin sections and on bulk samples, Environmental Scanning Electron Microscopy and microchemical investigations (ESEM-EDX) were carried out, utilizing a ZEISS EVO LS 10 with LaB6 source. Additionally, X-Ray Diffraction analyses (XRD) were performed for acquiring qualitative and semi-quantitative data on the crystalline phases 
present in a concentration of at least 3-4\%. This determination was obtained through a Philips PW 1730 diffractometer equipped with a copper anticathode and a nickel filter. The measurement conditions have a diffraction interval of $2 \theta$, between $5^{\circ}$ and $50^{\circ}$, and a $2^{\circ}$ minute step at $40 \mathrm{kV}$ voltage and $30 \mathrm{~mA}$ current intensity.

\begin{tabular}{|c|c|c|}
\hline Site & Sample & Location of sampling \\
\hline \multirow{5}{*}{$\begin{array}{l}\text { Lower } \\
\text { Battery }\end{array}$} & PB SF 1 & $\begin{array}{l}\text { W-N wall, } 2^{\circ} \text { embrasure (counted } \\
\text { from the } N \text { side). } \\
\text { h } 125 \mathrm{~cm} \text { (from the sole) }-60 \mathrm{~cm} \\
\text { from the external right corner of the } \\
\text { mouth. }\end{array}$ \\
\hline & PB SF 2 & $\begin{array}{l}\text { W-N wall, } 2^{\circ} \text { embrasure (counted } \\
\text { from the N side). } \\
\text { S cheek, h } 130 \mathrm{~cm} \text { (from the sole) - } \\
230 \mathrm{~cm} \text { from the external left corner } \\
\text { of the mouth. }\end{array}$ \\
\hline & $\begin{array}{l}\text { PB SF } 5 \\
\text { (salts } \\
\text { effloresc.) }\end{array}$ & $\begin{array}{c}\text { Moat, west wall, between } 6^{\circ}-7^{\circ} \\
\text { embrasure (counted from the } \mathrm{N} \text { side). } \\
\mathrm{N} \text { cheek, h } 125 \mathrm{~cm}-130 \mathrm{~cm} \text { from the } \\
6^{\circ} \mathrm{embrasure} .\end{array}$ \\
\hline & PB SF 6 & $\begin{array}{c}\begin{array}{c}\text { External part of the Fort, at the } \\
\text { entrance by the sea. }\end{array} \\
\end{array}$ \\
\hline & PB SF ramp & $\begin{array}{l}\text { Belonging to the upper part of the } \\
\text { ramp }\end{array}$ \\
\hline \multirow[b]{2}{*}{$\begin{array}{l}\text { Upper } \\
\text { Battery }\end{array}$} & PB SF 7 & \multirow{2}{*}{$\begin{array}{c}\text { Both from the masonry in the area } \\
\text { called "Nave para artillerìa y para la } \\
\text { guardia". h } 120 \mathrm{~cm}-270 \mathrm{~cm} \text { from the } \\
\mathrm{N} \text { wall. }\end{array}$} \\
\hline & PB SF 8 & \\
\hline Outcrop & PB SF 11 & $\begin{array}{c}\text { Eastern outer part of the Lower } \\
\text { Battery. }\end{array}$ \\
\hline
\end{tabular}

Table 1- Samples, sites and locations of sampling (for the description of the Fort elements ref. Spiteri, 1994)

\section{Results and Discussion}

Preliminary observations allowed us to identify the utilization of different materials, depending on the position and the function.

Coral limestones were identified in both the Batteries, by PLM observations (samples PB SF 2 and PB SF 8). The two samples of Scleractinian Reef Corals, probably ascribable to the family of Faviidae (Budd A. F. and Stolarski, 2011), have different wall structures, but showing the same primary intragranular porosity, where rare micritic calcite cement is present. In particular, the corallite having the structure observed in sample PB SF 2 is the mainly utilized and it was largely noticed in the: embrasures, banquettes, pavements and in the rests of the covered way. Considering the banquettes of the Lower Battery, the coral limestone was observed in specific zones like corners and embrasure entrance sills, thus parts which need strong materials. Indeed this rock shown high strength during the sampling. Nevertheless, both samples have an incomplete transformation of aragonite in calcite, since $\mathrm{XRD}$ results underline aragonite as dominant mineral, while calcite is only present or even in traces (Table 2).

Another sedimentary stone, a biogenic limestone (sample PB SF 1), was detected, through Optical Microscopy. It is characterized by macrofossils, as: lamellibranchia, foraminifera and bryozoa, set by scarce muddy cement, showing both a primary intragranular porosity and a secondary porosity mainly due to dissolution. In this case, diffraction analyses revealed calcite as dominant mineral, while quartz traces have been detected (Table 2). This kind of limestone was less utilized in comparison with the previous one.

Orogenic igneous rocks were identified, as basalt andesite of calcalkaline series in the masonry (samples PB SF 6 and PB SF 7), while basalt andesite of high-K calcalkaline series was collected from an outcrop present next to the entrance of the Lower Battery (sample PB SF 11). Notably, PLM observations revealed a porphyrytic - glomeroporphyrytic structure, mainly characterized by plagioclases and clinopyroxenes; in addition magnetite was also present. This is confirmed also by XRD analysis which shown albite and oligoclase as main crystal phases, followed by traces of augite and magnetite (Table 2). By Optical Microscopy study they were also noticeable zoned plagioclases with sericitized parts and devitrified zones in the vitric groundmass. Furthermore amygdales filled by zeolites were recognized and confirmed by ESEM-EDX analyses, detecting $\mathrm{Si}, \mathrm{O}, \mathrm{Al}, \mathrm{Ca}, \mathrm{K}, \mathrm{Na}$ and $\mathrm{Mg}$ in ascending order of abundance.

Finally, sub-aphyric andesite was identified by PLM analysis, in the upper part of the ramp of Lower Battery (sample PB SF ramp). The reddish hue shown by the stone is due to the presence of iron oxides.

All these volcanic rocks were largely observed in the masonry, especially in the Upper Battery, 
where they were utilized in the sole of the embrasures, where cannons were leant on. Additionally, the cobblestones present at the entrance of the Fort are possibly made by the same igneous rocks, as well as the base of the Lower Battery entrance.

Considering the environmental impact on the masonries, the mainly factor of surface deterioration can be attributed to biological colonization, in terms of moss and algae. In addition, salt efflorescences sampled from the moat (sample PB SF 5) revealed calcite as main crystalline phase recognized by XRD analysis (Table 2) and confirmed by ESEM-EDX investigations.

\begin{tabular}{c|c|c|c|c|c|c} 
SAMPLE & ARAGONITE & CALCITE & MAGNETITE & PLAGIOCLASE & PYROXENE & QUARTZ \\
\hline PB SF 1 & - & ++ & - & - & - & traces \\
\hline PB SF 2 & +++ & + & - & - & - & - \\
\hline PB SF 5 & - & +++ & - & - & - & - \\
\hline PB SF 6 & - & - & $?$ & +++ & traces & - \\
\hline PB SF 7 & - & - & traces & +++ & traces/+ & - \\
\hline PB SF 8 & ++ & traces & - & - & - & - \\
\hline PB SF 11 & - & - & - & +++ & + & +
\end{tabular}

Table 2 - X-Ray Powder Diffraction data of PB SF samples. Legend : +++ =dominant; ++ = abundant; + =present; traces; - =absent

\section{Conclusions}

The materials characterization highlighted four kind of stones in the masonries: corallite, biogenic limestone, basalt andesite and andesite. It has been observed that their use depends on the function, thus according to the strength of the stones, they have been utilized in different parts.

Environmental impact is mainly due to natural and climate factors, as biodeterioration and salt efflorescences. These latter ones are mainly composed by calcite, highlighting the aggressive effects of high percentage of relative humidity and water permeation phenomena which can dissolve calcium carbonate.

Therefore further analysis are ongoing to complete these preliminary investigations, in order to produce guidelines for current and future conservation works.

\section{Acknowledgments}

The authors want to thank the staff of Patronato de Portobelo y San Lorenzo for the availability and collaboration. A special acknowledgment to Franco Corticelli for ESEM-EDX analysis support.

\section{References}

Budd A. F. and Stolarski J. (2011), Corallite Wall and Septal Microstructure in Scleractinian Reef Corals: Comparison of Molecular Clades Within the Family Faviidae. Journal of Morphology 272. pp. 66-88.

Gobierno Nacional República de Panamá, Autoridad Nacional del Ambiente, Atlas Ambiental, (2010) pp. 26-31.

Gobierno Nacional República de Panamá, Instituto Nacional De Cultura Dirección Nacional Del Patrimonio Histórico, Oficina Del Casco Antiguo, Ciudad De Panamá (OCA) (2014), Plan de emergencia de la propiedad C135, Fortificaciones de la Costa Caribeña de Panamá: Portobelo San Lorenzo. pp. 13-36.

http://whc.unesco.org/en/list/135

Osorio Ugarte K. (2015), Report for the UNESCO World Heritage centre about the state of conservation. Fortifications On The Caribbean Side Of Panama: Portobelo - San Lorenzo. pp. 10.

Spiteri, S.C. (1994). Illustrated Glossary of Terms used in Military Architecture.

Tejera Davis, E., (2007), Panamá: Guía de Arquitectura y Paisaje - An Architectural and Landscape Guide, Ed. bilingüe [ $1^{\mathrm{a}}$ ed.], Junta de Andalucia, Instituto Panameño de Turismo, Gobierno de España.

World Monuments Fund (2003), Portobelo - San Lorenzo: An approach to integrated conservation for sites containing endangered cultural and natural resources. pp. 8-71. 